\title{
The Increasing Importance of Proximity for Exports from U.S. States
}

\author{
Cletus C. Coughlin
}

ncome, trade policies, transportation costs, technology, and many other variables combine to determine the levels of international trade flows. Not only do changes in these determinants affect the levels of trade flows, they can also have important consequences for the geographic pattern of a country's trade. Some changes are generally thought to increase the proportion of a country's trade with nearby countries relative to its other trading partners, while other changes tend to decrease this proportion. For example, if a country enters into a trade agreement with nearby countries, it is likely that the country's share of trade with nearby countries will increase relative to its trade with other trading partners. On the other hand, declining transportation costs can reduce the cost disadvantage of trading with distant countries and could thereby increase trade with more distant countries relative to those nearby.

This paper focuses on the changing geography of merchandise exports from individual U.S. states to foreign countries. Due to data limitations, exports of services are not examined. Two basic questions are addressed. First, how has the geographic distribution of exports from individual U.S. states changed? Second, which changes in the economic environment appear to account for the observed changes in the geographic distribution of state exports?

A useful measure for analyzing the changing geography of trade is the distance of trade, which is simply the average distance that a country's (state's) international trade is transported. ${ }^{1}$ If a country's (state's) distance of trade is declining (increasing)

\footnotetext{
1 The calculation is straightforward. Assume a state's exports are shipped to two countries and that the value of exports sent to one country, which is 1,000 miles away, is $\$ 800$ and the value sent to the other country, which is 3,000 miles away, is $\$ 1,200$. Thus, 40 percent of the state's exports are transported 1,000 miles and 60 percent are transported 3,000 miles. The distance of trade is 2,200 miles $(40 \% \times$ $1,000+60 \% \times 3,000)$.
}

over time, then its trade is becoming more (less) intense with nearer countries relative to countries farther away. In other words, a declining (increasing) distance of trade means that the shares of a country's (state's) trade with nearby trading partners is rising (falling) relative to trade with its more distant trading partners.

The analysis begins by summarizing the facts and the explanations concerning the geographic distribution of exports throughout the world. An important feature of the economic geography of trade flows is the distance that separates a state from its trading partners. Distance is generally thought to play a key role in the geographic distribution of trade for two reasons. First, transportation costs are higher for longer distances. Second, the costs of accessing information about foreign markets and establishing a trade relationship in those markets are higher for longer distances. ${ }^{2}$ Thus, a country's trade with more distant countries is deterred.

Despite the "death of distance" associated with the communications revolution, proximity appears to be increasingly important for trade flows. ${ }^{3}$ Using the bilateral trade flows of 150 countries, Carrere and Schiff (2004) find that during 1962-2000 the distance of (non-fuel merchandise) trade declines for the average country and that countries with a declining distance of trade were twice as numerous as those with an increasing distance of trade.

After reviewing the geography of exports from the perspective of individual countries throughout the world, I examine the geography of the exports

\footnotetext{
2 See Rauch (1999) for additional discussion of this point.

3 The death of distance has become a popular term because of The Death of Distance: How the Communications Revolution Will Change Our Lives by Frances Cairncross (1997). The book focuses on the economic and social importance of how advances in technology have virtually eliminated distance as a cost in communicating ideas and data. Possibly, this death of distance has made foreign direct investment and trade with proximate countries a more efficient way to serve markets than trade over long distances.
}

Cletus C. Coughlin is deputy director of research at the Federal Reserve Bank of St. Louis. Molly D. Castelazo provided research assistance.

Federal Reserve Bank of St. Louis Review, November/December 2004, 86(6), pp. 1-18.

(C) 2004, The Federal Reserve Bank of St. Louis. 
from individual U.S. states to their trading-partner countries. The distance of trade is calculated annually for each state beginning in 1988, the first year of detailed geographic data for individual states.

Similar to the finding for the majority of countries, the majority of, but not all, states show a declining distance of trade.

The findings for individual states allow for an examination of some explanations that may account for the changing geographic distribution of exports at the state level. The uneven income growth of trading partners, the implementation of the North American Free Trade Agreement (NAFTA), and changing transportation costs are the "usual suspects." Possibly, incomes of nearby trading partners have increased more rapidly than incomes of more distant trading partners. Such a development might stimulate trade with nearby trading partners (relative to those more distant) so that a state's distance of trade declines. Similarly, the implementation of NAFTA, by reducing trade barriers between the United States and its major North American trading partners, might tend to decrease a state's distance of trade. Finally, it is possible that transportation costs have changed to increase the attractiveness of trading with nearby countries. My goal is to provide suggestive evidence on how these three factors have changed the geography of the exports of states, which in turn provides insights concerning the changing geography of total U.S. exports.

\section{THE CHANGING GEOGRAPHY OF WORLD TRADE}

During the second half of the twentieth century, the volume of international trade throughout the world increased more rapidly than output. Baier and Bergstrand (2001) attempted to identify the reasons for the growth of international trade between the late 1950 s and the late 1980 s. They estimated that declines in transportation costs explained about 8 percent of the average trade growth of several developed countries, tariff-rate reductions about 25 percent, and income growth the remaining 67 percent. The question for the current study is straightforward. Have these determinants, which are related to one another, changed in such a way that would alter systematically the geography of state export flows? To date, systematic evidence relating these determinants to state export flows is lacking. In fact, little evidence exists as to how changes in these determinants of trade have affected the geography of world trade flows.

\section{Changing Transportation Costs- Usual Suspect No. 1}

The costs of transporting goods from a producer in one country to a final user in another country are large. Putting a precise number on "large" is very difficult and undoubtedly varies across goods and countries. Despite this difficulty, Anderson and van Wincoop (forthcoming) estimate international transportation costs for industrialized countries to be equivalent to a tax of 21 percent. Additional transportation costs are incurred to move internationally traded goods within exporting countries and within importing countries. Not surprisingly, changes in transportation costs can have large effects on trade flows. Not only can reductions in transportation costs lead to increased trade flows directly, but also indirectly by affecting the profitability of production in specific locations.

A point that might not be intuitively obvious is that a decline in transportation costs might cause either an increase or a decrease in a country's (state's) distance of trade. In the context of ocean shipping costs, it depends on the nature of the change in transportation costs.

Ocean shipping transportation costs can be divided into those unrelated to distance, known as dwell costs, and those related to distance, known as distance costs. Dwell costs cover various aspects, such as the cost of loading and unloading ships and the cost (including time) of queuing outside a port waiting to be serviced. On the other hand, distance costs are related positively to the distance from port to port. For example, the longer the distance between ports, the larger the fuel costs of transporting a given shipment.

In theory, reductions in both dwell costs and distance costs increase international trade flows; however, their effects on the distance of trade differ. A reduction in dwell costs increases the incentive to trade with nearby locations relative to distant locations; this is so because dwell costs make up a larger proportion of total transport costs for shorter distances. ${ }^{4}$ Thus, a reduction in dwell costs tends to

\footnotetext{
4 For example, assume dwell costs of $\$ 100,000$ and distance costs per mile of $\$ 200$. If so, then the cost of a trip of 1,000 miles is $\$ 300,000$ and a trip of 4,500 miles is $\$ 1$ million. Thus, for the shorter (longer) trip the respective shares of the transportation costs are 33 (10) percent for the dwell costs and 67 (90) percent for the distance costs. As a result, a reduction in dwell costs, say from $\$ 100,000$ to $\$ 50,000$, has a larger proportional effect on costs for the shorter trip; a reduction in distance costs, say from $\$ 200$ per mile to $\$ 100$ per mile, has a larger proportional effect on costs for the longer trip.
} 
reduce the distance of trade. On the other hand, a reduction in distance costs increases the incentive to trade with distant locations relative to nearby locations. The reduced cost per mile causes a larger proportional decrease in transport costs for longer distances. Thus, a reduction in distance costs tends to increase the distance of trade. ${ }^{5}$

Because evidence on dwell and distance costs is limited, it is very difficult to reach firm conclusions concerning their evolution and, in turn, their effects on the distance of trade. Hummels (1999) provides some evidence suggesting technological changes associated with containerization have reduced both dwell and distance costs. ${ }^{6}$ Containerization is a system of inter-modal transport that uses standardsized containers that can be loaded directly onto container ships, freight trains, and trucks. Dwell costs are reduced because ships spend less time in port and the cargo can be handled more efficiently. Meanwhile, the larger and faster ships allowed by containerization have reduced shipping costs on a ton-mile basis while the ship is moving between ports. It is likely, however, that containerization lowered dwell costs relatively more than distance costs. In addition, containerization, by eliminating the unpacking and packing of cargoes at every change in transport mode, likely reduced the cost of the inland movement of goods by making the inter-modal transfer of goods easier. Such changes should tend to reduce the distance of trade.

Containerization, however, is only one of the many changes that have affected transportation costs. Regulatory policies and energy prices are two additional factors. Whether transportation costs have in fact declined in recent decades is uncertain because of the lack of evidence on this issue. For example, Carrere and Schiff (2004) conclude that transportation costs have not necessarily declined across all modes of transportation. First, they cite evidence provided by Hummels (1999), who found

\footnotetext{
5 A decline in transportation costs might not affect the distance of trade. Eichengreen and Irwin (1998) note that the cost of transporting goods over various distances could decline proportionately. In this case, which they call "distance-neutral" technological progress, such a decline in transportation costs would tend to leave the distance of trade unchanged.

6 Hummels (1999) identified as important the following institutional changes that have affected ocean shipping: open registry shipping, which allows ships to be registered under flags of convenience to avoid some regulatory and manning costs imposed by some countries, and cargo reservation policies, which were to designed to ensure that a country's own ships were granted a substantial share of that country's liner traffic.
}

that ocean freight rates have increased, while air freight rates have declined rapidly. Hummels also found evidence that overland transport costs in the United States have declined relative to ocean freight rates. In fact, according to Glaeser and Kohlhase (2004), the costs of moving goods by rail and by truck within the United States have fallen substantially in a nearly continuous manner since $1890 .{ }^{7}$

While far from precise in terms of quantifying the changes in transportation costs, these findings are consistent with recent changes in the relative shares of the methods used to transport U.S. exports. Over time, air and land shipments have displaced ocean shipments. Figure 1 shows that between 1980 and 2002 the shares of air and land shipments increased by 11.9 and 14.5 percentage points, respectively, while the share of ocean shipments declined by 26.4 percentage points. As a result, the majority of U.S. exports are no longer shipped on ocean vessels. In fact, in 2002, shipments by air and land accounted for larger shares of exports than shipments by sea.

A second source of evidence relevant to changes in transportation costs relies on studies that estimate the relationship between distance and international trade flows. ${ }^{8}$ Numerous studies have generated estimates of the distance sensitivity of trade or, using more precise terminology, the distance elasticity of trade: that is, the percentage change in trade flows associated with a given percentage increase in the distance separating one country from its trading partners. These studies find, not surprisingly, that the larger the distance that separates two countries, the smaller the value of trade moving between them. More important for the current discussion is the common finding that distance is playing a changing role over time in the geographic distribution of trade. For example, results by Frankel (1997) indicate that

7 Glaeser and Kohlhase (2004) find that the cost of moving goods has declined by roughly 90 percent since 1890 . The costs of transporting goods by rail and by truck have declined at annual rates of 2.5 percent and 2.0 percent, respectively. As a result, they conclude that the cost of moving goods within the United States is no longer an important component of the production process.

8 Using distance as a proxy for transportation costs is problematic for numerous reasons. Distance is generally measured with the "great circle" formula. Actual transportation routes are not this direct. In addition, the use of distance assumes one route between trading regions. Trade between two geographically large countries, such as the United States and Canada, is conducted over many routes. Multiple routes and multiple modes of transportation increase the doubts that distance is a good proxy for transportation costs. As discussed in the text, many transportation costs, such as dwell costs, clearly do not vary with distance. Finally, actual freight rates often bear little connection to distance traveled. 


\section{Figure 1}

\section{U.S. Exports by Transport Mode, 1980-2002}

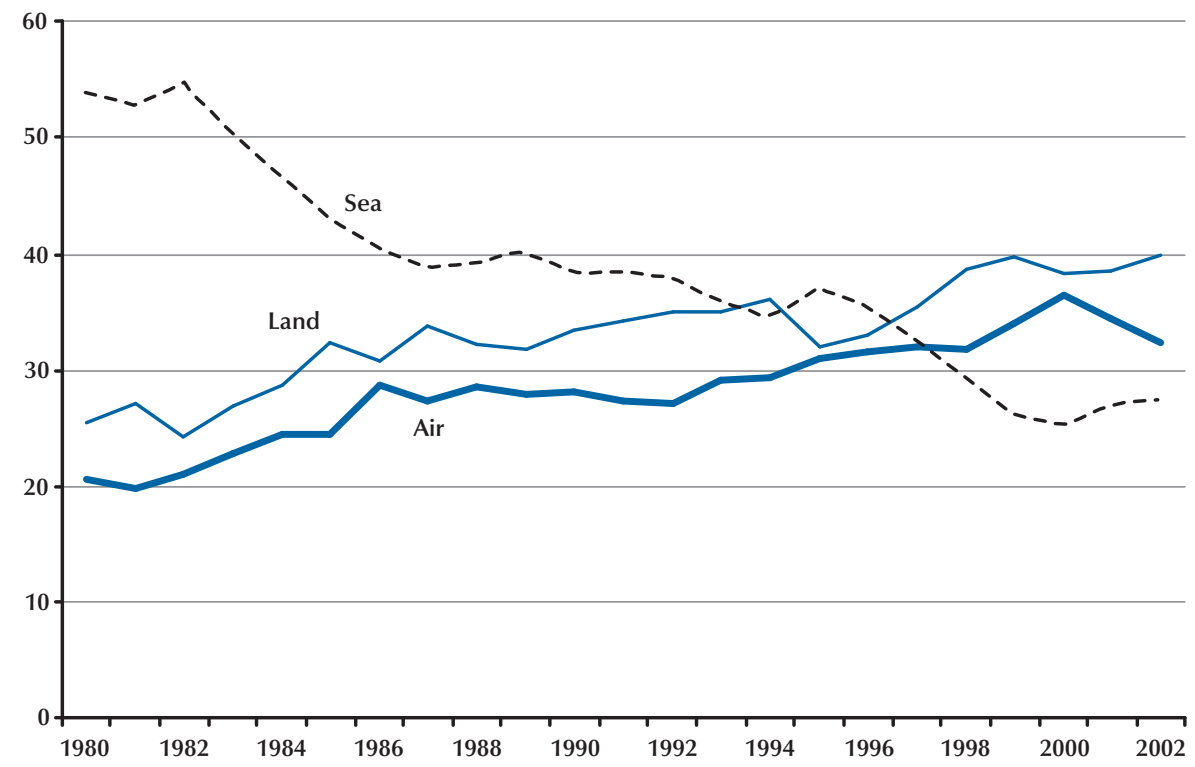

NOTE: The variable Land was created by subtracting the sum of air and vessel exports from total exports.

SOURCE: U.S. Bureau of the Census.

if the distance separating a country from two of its trading partners differed by 10 percent, then trade flows between the country and its more distant trading partner (relative to the country and its nearby partner) were 4 percent less during the 1960s and 7 percent less during the 1990s. Overall, the majority of studies indicate that the distance sensitivity of trade is not shrinking, but rather increasing. ${ }^{9}$ Such

9 Disdier and Head (2004), in a thorough examination of numerous studies using gravity models, conclude that the impact of distance is increasing, albeit slightly, over time. Brun et al. (2003) and Coe et al. (2002) reach a similar conclusion. Berthelon and Freund (2004) find that, rather than a shift in the composition of trade, an increase in the distance sensitivity for more than 25 percent of the industries examined accounts for this result. Research by Rauch (1999), contrary to most studies, finds that the effect of increased distance on trade has declined since 1970.

${ }^{10}$ Hummels (2001) identified numerous costs associated with shipping time and its variability. Lengthy and variable shipping times cause firms to incur inventory and depreciation costs. Inventory-holding costs include the financing costs of goods in transit and the costs of maintaining larger inventories at final destinations to handle variation in arrival times. Examples of depreciation, which reflect any reason to prefer a newer good to an older good, include the spoilage of goods (fresh produce), goods with timely information content (newspapers), and goods with characteristics whose demand is difficult to forecast (fashion apparel). a change would tend to decrease the distance of trade.

A third piece of evidence concerning transportation costs highlights the impact of time. ${ }^{10}$ The cost consequences of delays can be quite large. Hummels (2001) has estimated that each day saved in shipping time was worth 0.8 percent of the value of manufactured goods. Overall, faster transport between 1958 and 1998 due to increased air shipping and speedier ocean vessels was equivalent to reducing tariffs on manufactured goods from 32 percent to 9 percent. ${ }^{11}$

Time costs have likely played a key role in the change in shipping modes. Because shipping by air is much faster than shipping by sea, the decline in air shipping prices relative to ocean shipping prices has made the saving of time less expensive. This has

\footnotetext{
11 In general, transportation costs, including time costs, have risen as a result of the terrorist attacks of September 11, 2001. Insurance rates, especially for shipping in the Middle East, have increased sharply. Additional scrutiny of containers has also increased costs. According to the Organisation for Economic Co-operation and Development (2002), these costs could run from 1 to 3 percent of trade. Moreover, additional security measures cause delays for importers and exporters that further increase transportation costs.
} 
led to relatively large increases in air shipping and contributed to an increasing frequency of the various stages of the production of final goods occurring in different countries. The timeliness of air shipping can play a key role in the international trade of intermediate goods that characterizes international production fragmentation.

Some doubts arise about whether transportation costs have truly declined when distances of trade are examined. Carrere and Schiff (2004) examined the distance of trade for approximately 150 countries between 1962 and 2000. ${ }^{12}$ They found that the distance of trade declined for the average country worldwide. For every country with an "empirically significant" increasing distance of trade, there are nearly two countries with a decreasing distance of trade. ${ }^{13}$ For the average country's exports during 2000 , the distance of trade was slightly less than 4,000 miles. The average decline in the distance of trade between 1962 and 2000 was approximately 5 percent. For the United States the distance of trade based on exports was roughly 4,160 miles; however, contrary to the average country, the distance of trade for U.S. exports increased. Over the entire period, the distance of trade for U.S. exports increased by slightly less than 8 percent. The U.S. distance of trade did not increase in a consistent pattern throughout the 39-year period. In fact, during the 1980s and 1990s, the U.S. distance of trade declined.

A declining distance of trade, however, does not preclude declining transportation costs. As discussed previously, a decline in transportation costs can cause either an increase or a decrease in the distance of trade. If the decline is due to a reduction in dwell costs, then the distance of trade will tend to decline. It is possible that the distance of trade is trending downward because of changes in other determinants. I now turn to one possibility, a proliferation of regional trade agreements.

\footnotetext{
${ }^{12}$ The calculation of the distance of trade (DOT) from country $i$ during time period $t$ is straightforward. $D O T_{i}=\Sigma d_{i j} s_{i j}$, where $d$ is the (spherical) distance from the leading (economic) city in country $i$ to the leading city in destination country $j$ and $s$ is the share of $i$ 's exports to country $j$. The summation occurs over all destination countries. A simple numerical example is contained in footnote 1

${ }^{13}$ The authors define empirically significant as an absolute change in the estimated distance of trade of more than 5.5 percent. For the sample of 150 countries, 77 countries had an empirically significant negative change in either the distance of exports or imports, while 39 countries had an empirically significant positive change.
}

\section{Regional Trade Agreements - Usual Suspect No. 2}

A regional trade agreement eliminates barriers for trade flows between members, while maintaining the barriers for trade flows between members and nonmembers. Standard customs union theory predicts that these agreements will lead to increased trade between member countries (termed trade creation) and decreased trade between members and nonmembers (termed trade diversion). Because such agreements tend to be formed between neighboring countries, it is reasonable to expect that regional trade agreements will decrease a member's distance of trade. The stronger the effects of both trade creation and trade diversion, the larger is the decline in the distance of trade for a member.

Carrere and Schiff (2004) examine the impact of NAFTA and seven other regional integration agreements on the evolution of the members' distance of trade. Almost without exception, they find that regional trade agreements tend to reduce the distance of trade for exports. In other words, regional trade agreements, such as NAFTA, change the geographic trade pattern toward larger shares of trade with nearby relative to more distant trading partners.

\section{Uneven Income Growth- Usual Suspect No. 3}

A country's distance of trade can be affected by the pattern of income growth of its trading partners. Other things the same, if a country's nearby trading partners have greater income growth relative to its more distant trading partners, the country's distance of trade will decline because trade with its nearby partners will increase relative to trading with more distant partners.

Carrere and Schiff (2004) provide some examples, as well as regression results, to suggest this explanation may be important. They note that countries in the East Asia-Pacific region tended to grow faster than the world average during 1962-79, 1980-89, and 1990-2000. For each period, the trend distance of trade is negative for this region. A similar example involves the countries in NAFTA. The distance of trade tended to increase during 1962-89 and decrease during 1990-2000. Consistent with this explanation, growth in the NAFTA countries was below the world average during 1962-1989 and above the world average during 1990-2000. 
Table 1

Export Destination Share by Region (\%)

\begin{tabular}{lccc} 
& $\mathbf{1 9 8 8 - 9 2}$ & $\mathbf{1 9 9 3 - 9 7}$ & $\mathbf{1 9 9 8 - 2 0 0 2}$ \\
\hline Canada & 20.4 & 22.4 & 23.4 \\
Mexico & 7.9 & 9.6 & 13.7 \\
Latin America & 6.4 & 7.8 & 7.4 \\
$\quad$ and the Caribbean & & & \\
Europe & 27.8 & 22.8 & 23.2 \\
Asia & 33.2 & 33.9 & 29.1 \\
Africa & 1.7 & 1.4 & 1.2 \\
Oceania & 2.5 & 2.2 & 2.0
\end{tabular}

\section{International Production Fragmentation- A New Suspect}

In addition to the usual suspects, one new suspect has emerged: international production fragmentation. This development has led to major changes in the location of production and trade flows. A lack of data precludes an empirical examination of this explanation for state-level exports. Nonetheless, for completeness, a brief discussion of the relationship between international production fragmentation and the distance of trade seems warranted.

One feature of the expanding integration of world markets is that companies are outsourcing increasing amounts of the production process. This internationalization of production allows firms to achieve productivity gains by taking advantage of proximity to markets and/or low-cost labor. The net effect on the distance of trade is unclear. Despite locating production close to markets, the likely reduction in the distance of trade is uncertain because it is unclear how the increased use of low-cost labor will affect the distance of trade. One can easily find examples for the United States, such as the growth of maquiladoras in Mexico, which are associated with a declining distance of trade. On the other hand, the increased use by U.S. firms of low-cost labor in China tends to increase the distance of trade.

Another factor contributing to a declining distance of trade for the United States is the increasing use of "just-in-time" inventory management. New information and communications technology have propelled this management. For industries, such as apparel, in which timely delivery has become increasingly important, the distance of trade has decreased. Evans and Harrigan (2003) show that U.S. apparel imports have shifted from Asian countries to Mexico and Caribbean countries. ${ }^{14}$

The increasing importance of international production fragmentation is consistent with findings by Berthelon and Freund (2004) on the increasing distance sensitivity of trade. They find an increasing distance sensitivity of trade for 25 percent of the industries they examined. Accordingly, trade with nearby countries has become more attractive relative to trade with more distant countries. This increasing distance sensitivity might be the result of technological change that enhances the advantages of proximity. One consequence of this change is an increased share of trade between the countries within a region, such as between the countries in North and South America, relative to trade across regions, such as between countries in North America and East Asia.

\section{GEOGRAPHY OF U.S. STATE EXPORTS}

The distance of trade for the United States can be analyzed by taking a close look at the geography of exports using state data. In view of the declining U.S. distance of trade during the past two decades, it is reasonable to expect that the change in the distance of trade (using state export data summed over all states) will indicate relatively more intense trade with proximate regions than with distant regions.

The data in Table 1 show how the destination of U.S. exports has changed for three five-year periods during 1988-2002.15 The destinations for U.S. exports are split into Canada and Mexico, the two major North American trading partners of the United States as a whole, and then the rest of the world is split roughly into continents. Comparing 1988-92 with 1998-2002, it is clear that Canada, Mexico, and Latin America and the Caribbean are the destinations for increasing shares of U.S. exports, while Europe, Asia, Africa, and Oceania are the destinations for decreasing shares of U.S. exports. The shift in the share between the regions with an

\footnotetext{
14 Abernathy et al. (1999) argue that three retail apparel/textile regions are developing in the world-the United States plus Mexico and the Caribbean Basin, Japan plus East and Southeast Asia, and Western Europe plus Eastern Europe and North Africa.

15 Export shares are calculated by dividing U.S. exports to each region (averaged across five-year periods) by total U.S. exports to all seven regions (averaged across five-year periods). Regions are constructed using the top 50 export markets for each state, which account for more than 90 percent of each state's total exports. The definition of regions used for Tables 1 and 6 is not identical to the one used by Coughlin and Wall (2003).
} 


\section{Figure 2}

\section{National Distance of Trade, Calculated Using State-to-Country Distances, 1988-2002}

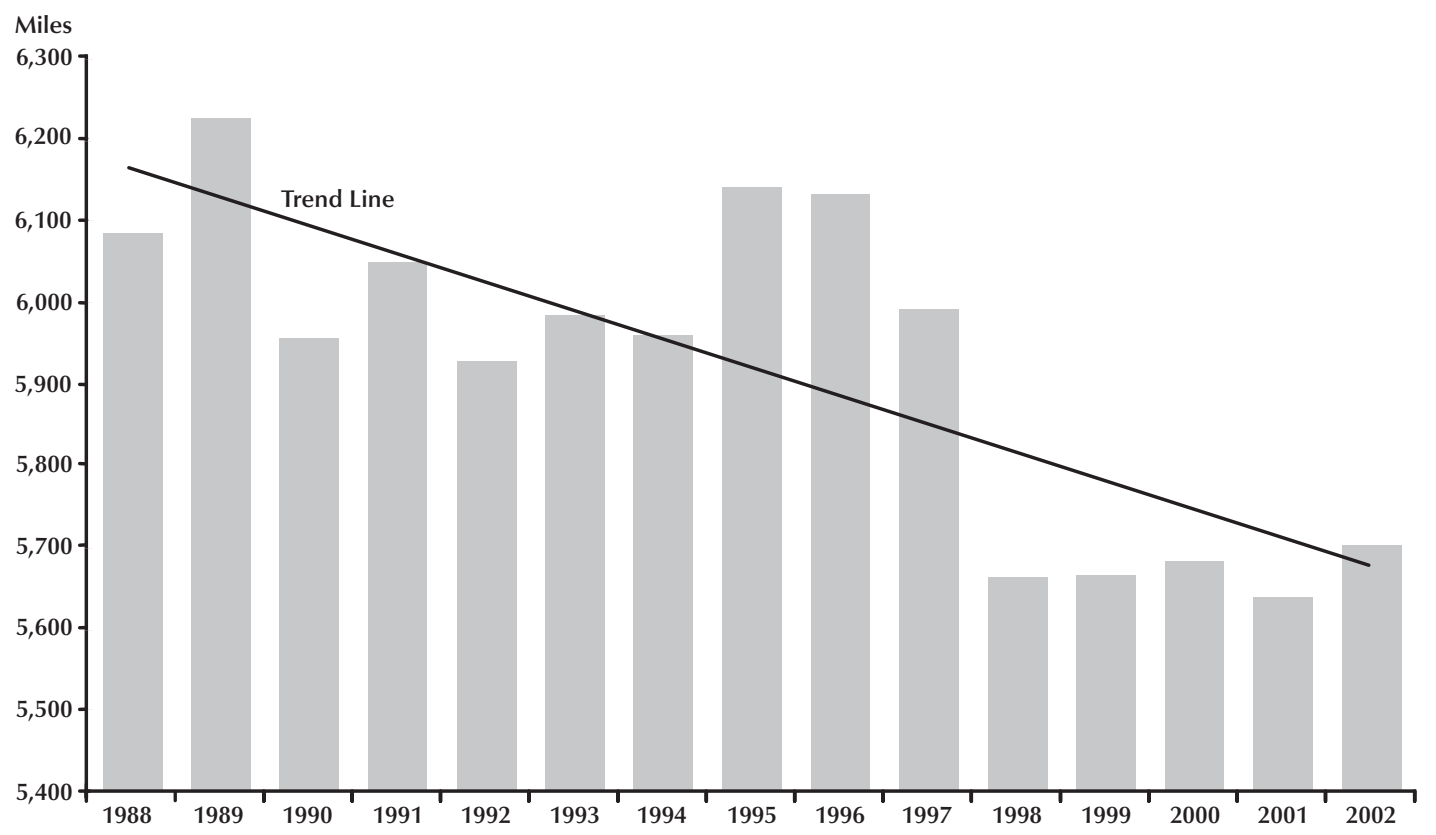

increasing share and those with a decreasing share was 9.8 percentage points. Most noteworthy were the increases by Mexico and Canada of 5.8 and 2.9 percentage points, respectively, and the decreases in export shares for Europe and Asia of 4.6 and 4.1 percentage points, respectively.

The changing export shares of proximate and distant regions are suggestive of the changing distance of trade for the nation as a whole. Figure 2 shows the yearly national distance of trade from 1988-2002. ${ }^{16}$ The distance of trade is substantially lower for the years at the end of the period compared with the earlier years. The range of national distance of trade was 5,664 to 5,702 miles for 1998 through 2002, while no year prior to 1998 had a distance of trade less than 5,930 miles. ${ }^{17}$

Because showing the distance of trade for each

${ }^{16}$ This measure was calculated using the top 50 export markets for each state.

17 The fact that the U.S. distance of trade measure calculated by Carrere and Schiff (2004) is substantially less than my measure reflects various factors, but most notably how our different measures deal with the impact of trade with Canada and Mexico. Carrere and Schiff use the distance between national capital cities (e.g., Washington, D.C., to Ottawa and Mexico City), while I use the distance between the major economic city in a state to the major economic city in Canada (Toronto) and in Mexico (Mexico City). For 2002 this methodological difference contributes 369 miles to the gap between the two measures. state (51) for each year (15) would yield a very large number of observations (765), I have chosen to summarize the data. ${ }^{18}$ Figure 3 shows the distribution of distance of trade across all states at the beginning of the sample period in the upper histogram and at the end of the sample period in the lower histogram. ${ }^{19}$ Measured on the horizontal axis is the distance of trade for the following ranges in miles: 1,000 to 3,$000 ; 3,000$ to 5,$000 ; 5,000$ to 7,$000 ; 7,000$ to 9,$000 ; 9,000$ to 11,$000 ; 11,000$ to 13,000 ; and 13,000 to 15,000 . The vertical axis shows the percentage of states with a distance of trade falling into the given ranges. For 1988, two-thirds of the states had a distance of trade within the 5,000 to 7,000 mile range. Two states, Hawaii and Alaska, were outliers with distances of trade in the 13,000 to 15,000 mile range.

Comparing 2002 with 1988 , one can easily see the declining distance of trade in the figure. Twothirds of the states fell into the 5,000 to 7,000 mile range in 1988 , whereas 45.1 percent fell into that range in 2002. Generally speaking, the decrease in the 5,000 to 7,000 mile range was matched by an

\footnotetext{
${ }^{18}$ For convenience, Washington, D.C., is referred to as a state.

${ }^{19}$ A state's distance of trade was calculated using its top 50 export markets.
} 


\section{Figure 3}

\section{Probability Distribution of State Distance of Trade in 1988 and 2002}
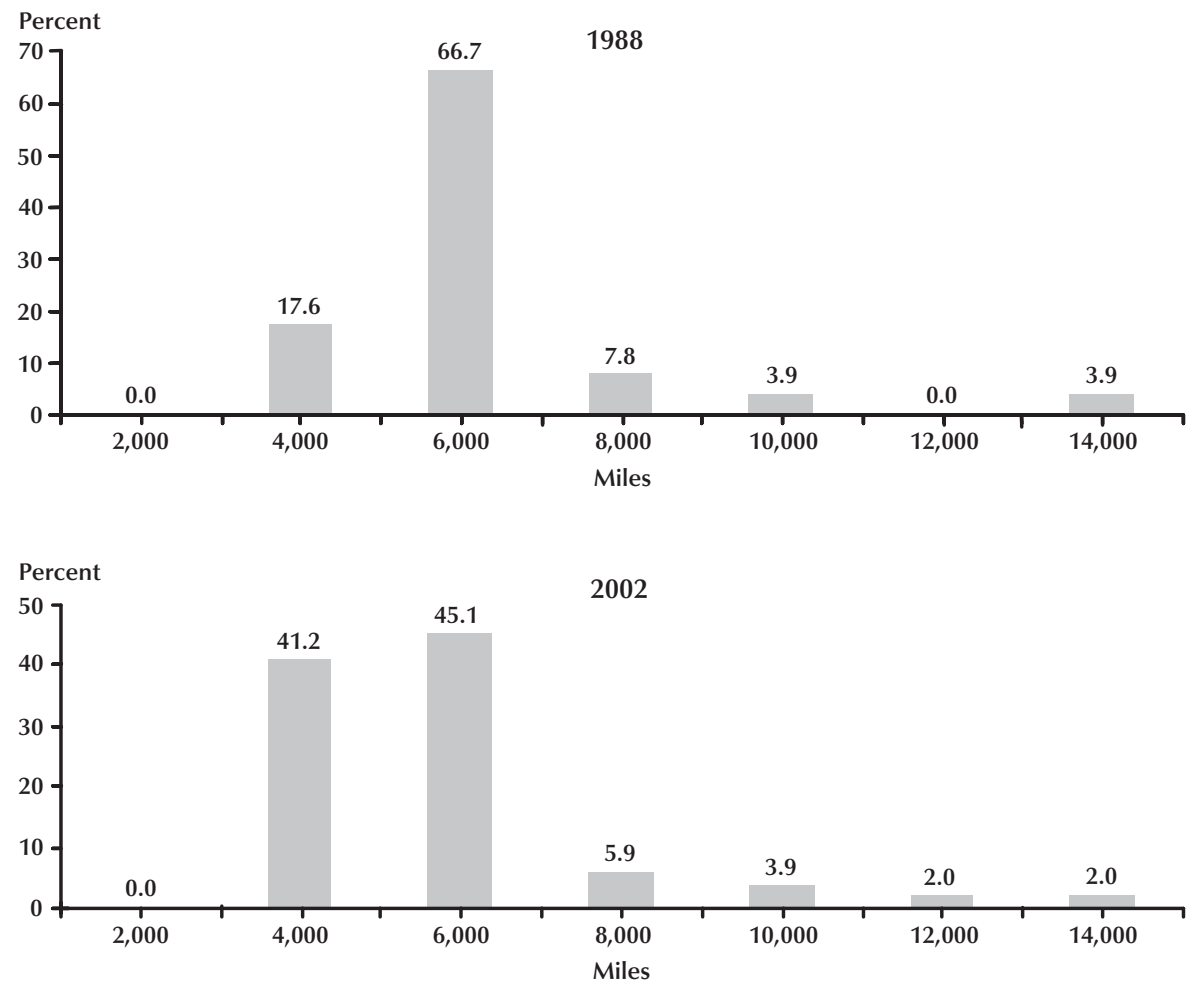

increase in the 3,000 to 5,000 mile range. For 1988 the percentage of states in the 3,000 to 5,000 mile range was 17.6 percent, while for 2002 the percentage of states in this range was 41.2 percent.

Additional suggestive information about changes in the state-level export distance of trade, especially how the changes vary across states, was generated by estimating a simple regression equation. Similar to Carrere and Schiff (2004), the natural logarithm of a state's distance of trade ( $\ln D O T)$ was regressed against time $(t)$. For each state, a separate regression was estimated relating the state's distance of trade to time using annual data from 1988-2002. The specific equation was as follows:

$$
\ln D O T=\alpha+\beta t+\varepsilon,
$$

where $\alpha$ is the intercept term, $\beta$ is the coefficient relating time to the distance of trade, and $\varepsilon$ is the error term.

Table 2 shows the estimated $\beta$ for each state, ordered from the smallest (i.e., most negative) value to the largest. The estimate for Montana, -0.0429 , was the smallest, while the estimate for Vermont,
0.0388 , was the largest. Regressions for 40 of the 51 states generated negative estimates for $\beta$, while regressions for 11 of the 51 states generated positive estimates. ${ }^{20}$ Table 2 also shows the percentage change in the distance of trade based on the coefficient estimate. ${ }^{21}$ The smaller (i.e., more negative) the coefficient, the larger is the estimated percentage decline in a state's distance of trade. Twenty-seven states showed declines in their distance of trade that exceeded 10 percent, while five states showed increases of more than 10 percent.

\section{POSSIBLE DETERMINANTS OF THE CHANGING GEOGRAPHY OF STATE EXPORTS}

In light of the changing geography of state exports - toward relatively larger shares of trade

\footnotetext{
${ }^{20}$ Using the 5 percent level, only 1 of the 51 estimates is not statistically significant.

${ }^{21}$ The calculation of the estimated percentage change in the distance of trade follows from the fact that the coefficient estimate of $\beta$ is an instantaneous rate of growth. The formula is $\left(e^{\beta \times 14}-1\right) 100$.
} 


\section{Table 2}

Time-Trend Analysis of the Distance of Trade, 1988-2002

\begin{tabular}{|c|c|c|c|c|}
\hline State & State rank & $\begin{array}{l}\text { Coefficient } \\
\text { estimate, } \beta\end{array}$ & $t$ Statistic & $\begin{array}{l}\text { Estimated percentage change } \\
\text { in distance of trade }\end{array}$ \\
\hline$\overline{\text { Montana }}$ & 1 & -0.0429 & -42.2 & -45.2 \\
\hline Indiana & 2 & -0.0253 & -86.5 & -29.8 \\
\hline South Carolina & 3 & -0.0248 & -65.6 & -29.3 \\
\hline Mississippi & 4 & -0.0235 & -49.3 & -28.1 \\
\hline Wyoming & 5 & -0.0230 & -48.2 & -27.6 \\
\hline Texas & 6 & -0.0224 & -47.4 & -27.0 \\
\hline Alabama & 7 & -0.0213 & -53.7 & -25.7 \\
\hline North Carolina & 8 & -0.0191 & -86.5 & -23.4 \\
\hline Tennessee & 9 & -0.0171 & -54.6 & -21.3 \\
\hline Ohio & 10 & -0.0170 & -41.0 & -21.1 \\
\hline South Dakota & 11 & -0.0141 & -18.9 & -17.9 \\
\hline Illinois & 12 & -0.0113 & -26.5 & -14.7 \\
\hline Utah & 13 & -0.0110 & -18.1 & -14.2 \\
\hline lowa & 14 & -0.0108 & -31.9 & -14.1 \\
\hline Oklahoma & 15 & -0.0107 & -21.4 & -14.0 \\
\hline Kentucky & 16 & -0.0106 & -23.6 & -13.8 \\
\hline Pennsylvania & 17 & -0.0102 & -86.1 & -13.3 \\
\hline Nevada & 18 & -0.0102 & -11.8 & -13.3 \\
\hline New York & 19 & -0.0098 & -34.3 & -12.8 \\
\hline Louisiana & 20 & -0.0097 & -42.2 & -12.7 \\
\hline Alaska & 21 & -0.0093 & -48.5 & -12.2 \\
\hline Arizona & 22 & -0.0090 & -15.2 & -11.8 \\
\hline Georgia & 23 & -0.0086 & -27.1 & -11.3 \\
\hline Kansas & 24 & -0.0082 & -28.4 & -10.8 \\
\hline Florida & 25 & -0.0081 & -20.0 & -10.7 \\
\hline California & 26 & -0.0081 & -29.3 & -10.7 \\
\hline Wisconsin & 27 & -0.0079 & -27.2 & -10.4 \\
\hline Missouri & 28 & -0.0072 & -16.0 & -9.5 \\
\hline Nebraska & 29 & -0.0070 & -14.1 & -9.3 \\
\hline New Hampshire & 30 & -0.0060 & -18.2 & -8.1 \\
\hline Connecticut & 31 & -0.0054 & -18.9 & -7.3 \\
\hline Arkansas & 32 & -0.0048 & -14.4 & -6.5 \\
\hline Washington & 33 & -0.0039 & -11.3 & -5.4 \\
\hline Idaho & 34 & -0.0034 & -13.1 & -4.6 \\
\hline Oregon & 35 & -0.0033 & -15.1 & -4.5 \\
\hline Minnesota & 36 & -0.0025 & -12.9 & -3.4 \\
\hline Virginia & 37 & -0.0025 & -13.6 & -3.4 \\
\hline Colorado & 38 & -0.0021 & -6.3 & -2.9 \\
\hline Rhode Island & 39 & -0.0007 & -2.9 & -0.9 \\
\hline New Jersey & 40 & -0.0005 & -2.4 & -0.7 \\
\hline Massachusetts & 41 & 0.0003 & 1.0 & 0.4 \\
\hline Maine & 42 & 0.0024 & 4.8 & 3.4 \\
\hline West Virginia & 43 & 0.0031 & 9.2 & 4.4 \\
\hline Michigan & 44 & 0.0044 & 18.9 & 6.4 \\
\hline Hawaii & 45 & 0.0051 & 10.2 & 7.4 \\
\hline Maryland & 46 & 0.0058 & 13.0 & 8.4 \\
\hline District of Columbia & 47 & 0.0155 & 18.7 & 24.2 \\
\hline North Dakota & 48 & 0.0163 & 35.2 & 25.6 \\
\hline Delaware & 49 & 0.0209 & 42.9 & 34.0 \\
\hline New Mexico & 50 & 0.0277 & 25.6 & 47.4 \\
\hline Vermont & 51 & 0.0388 & 56.6 & 72.1 \\
\hline
\end{tabular}


with proximate countries - I examine the same explanations that apply to the changing world geography of trade. As will become apparent, any strong conclusions are precluded by analysis of the existing data.

\section{Changing Transportation Costs}

To generate some basic facts about state exports and distance, the following regression was estimated for each state using its top 30 export markets for each year from 1988 through 2002:

$$
E X P S H A R E=\alpha+\beta R G D P+\gamma D I S T+\varepsilon,
$$

where EXPSHARE is the share of a state's exports shipped to a specific country; $R G D P$ is the real gross domestic product (GDP) of the destination country; $D I S T$ is the distance from the state to the destination country; $\alpha, \beta$, and $\gamma$ are the parameters to be estimated; and $\varepsilon$ is the error term. ${ }^{22}$ Because higher real GDP should be associated with larger export shares, the expected sign for the estimate of $\beta$ is positive. Because longer distances between the exporting state and the destination country should proxy for higher transportation costs, the expected sign for the estimate of $\gamma$ is negative.

The results indicate that the higher the real GDP of a country, the higher is its export share. ${ }^{23}$ Not surprisingly, for the vast majority of states (45), the larger the distance that separates a state from an export destination, the smaller the export share of the destination country. Summary results for the estimate of $\gamma$ are listed in Table 3.24 An important question is how the estimated relationship between distance and export share is changing over time. In Table 3 the "Trend" column provides this information. Similar to the results cited earlier for the relationship between distance and trade flows using country data, the relationship between distance and trade shares using state data indicates that the effect of distance is increasing the trade shares of proximate countries at the expense of trade with distant countries. This holds for 42 of the 51 states-

\footnotetext{
22 The top 30 export markets can vary over time for a given state and vary across states. The countries used in the regressions for each state are available upon request from the author.

23 These results are not reported; however, they are available upon request from the author.

24 Strong statements concerning this evidence are not justified: Statistical significance at the 10 percent level was found for the relationship between distance and export share for 20 percent of the estimates.
}

for 38 states the sign of the parameter estimate for distance is negative, with a declining trend (i.e., becoming more negative), and for 4 states the sign of the parameter estimate for distance is positive, with a declining trend (i.e., becoming less positive). ${ }^{25}$

Thus, for most states the results suggest that the parameter estimate for distance is declining over time. Such a change should tend to decrease a given state's distance of trade over time because the export shares of more distant countries are declining more rapidly in latter periods. One possible explanation for these results is that changes in transportation costs now favor land transportation.

As mentioned previously, Glaeser and Kohlhase (2004) found that the costs of moving goods by rail and by truck within the United States have fallen substantially in a nearly continuous manner since 1890. Whether such declines also apply to trade with Canada and Mexico is unclear, but there are some reasons to think that these international transport costs have declined. Exports from the United States to Canada and Mexico are generally over land. From 1988 through 2002, roughly 90 percent of U.S. exports to Canada and Mexico were transported over land. Declining costs of transportation over land have tended to favor state exports to Canada and Mexico relative to trade with more distant locations. The importance of such a change, however, is difficult to separate from the effects of NAFTA.

\section{NAFTA}

NAFTA has the potential to affect a variety of trade barriers. Extending the previous discussion, a question is whether NAFTA has had any impact on transportation costs associated with crossing the border between the United States and Mexico. The answer appears to be no.

Seamless border crossings were envisioned as a feature of NAFTA; however, Haralambides and Londoño-Kent (2004) note that reality differs substantially from this vision. To complete the physical

\footnotetext{
25 Additional statistical analysis has been undertaken, the foundations of which can be found in Cheng and Wall (forthcoming), and has yielded similar results concerning how the distance coefficient has changed over time. For each of the five leading U.S. exports marketsCanada, Mexico, Japan, Germany, and the United Kingdom - the following two-step procedure was used. First, using annual observations covering five years (1988-92, 1993-97, and 1998-2002) and all states the share of a state's exports sent to a specific country was regressed on a time dummy and a state-country dummy. Second, the statecountry fixed-effect estimate was regressed on the distance from the state to the specific country. These results are available upon request from the author.
} 


\section{Table 3}

\section{The Distance Coefficient, $\gamma$}

\begin{tabular}{lclllc} 
State & Sign & Trend & State & Sign & Trend \\
\hline Alabama & - & Down & Montana & - & Down \\
Alaska & + & Down & Nebraska & - & Down \\
Arizona & - & Down & Nevada & - & Down \\
Arkansas & - & Down & New Hampshire & - & Down \\
California & - & Down & New Jersey & - & Down \\
Colorado & - & Down & New Mexico & + & Up \\
Connecticut & - & Down & New York & - & Down \\
Delaware & - & Up & North Carolina & - & Down \\
District of Columbia & - & Up & North Dakota & - & Up \\
Florida & - & Down & Ohio & - & Down \\
Georgia & - & Down & Oklahoma & - & Down \\
Hawaii & + & Up & Oregon & + & Down \\
Idaho & - & Down & Pennsylvania & - & Down \\
Illinois & - & Down & Rhode Island & - & Down \\
Indiana & - & Down & South Carolina & - & Down \\
lowa & - & Down & South Dakota & - & Down \\
Kansas & - & Down & Tennessee & - & Down \\
Kentucky & - & Down & Texas & - & Down \\
Louisiana & - & Down & Utah & - & Down \\
Maine & - & Up & Vermont & - & Up \\
Maryland & - & Up & Virginia & - & Down \\
Massachusetts & - & Down & Washington & - & Down \\
Michigan & - & Up & West Virginia & - & Down \\
Minnesota & - & Down & Wyoming & - & Down \\
Mississippi & - & Down & & - & - \\
Missouri & - & & & - & - \\
\hline
\end{tabular}

transfer of goods from the United States to Mexico at the key United States-Mexico border crossingthat is, from Laredo, Texas, to Nuevo Laredo, Tamaulipas-requires a significant commitment of time, vehicles, and manpower. The cross-border transfer may take from two to four days, involve three or more trucks and trailers, and require three or four drivers. For comparison, the driving time from Chicago to Laredo is two days.

The original NAFTA agreement provided that, as of December 18, 1995, Mexican and U.S. trucking companies would have full access to and from each country's border states. Then, as of January 1, 2000, this reciprocal access was to have been extended throughout both countries. Given the inefficiencies affecting the movement of goods between the United States and Mexico, the implementation of NAFTA had the potential to substantially reduce cross-border transport costs. ${ }^{26}$ However, for the period under consideration, the provisions governing cross-border trucking services were not in effect.

The Clinton administration, citing safety concerns, decided not to comply with the cross-border trucking services provisions. The lack of U.S. compliance produced gridlock in terms of implementing NAFTA's trucking services provisions. Following the

${ }^{26}$ Using estimates of the inefficiencies developed by Haralambides and Londoño-Kent (2004), Fox, Francois, and Londoño-Kent (2003) estimated that the elimination of the inefficiencies would cause U.S. exports to Mexico to increase by roughly $\$ 6$ billion per year. 
U.S. decision, a lengthy process involving much negotiation and a ruling by an arbitration panel to resolve the resulting disagreement ensued. ${ }^{27}$ What appears to be the last roadblock to implementing the trucking services provisions was eliminated in June 2004 when the U.S. Supreme Court gave the Bush administration the authority to open U.S. roads to Mexican trucks without first completing an extensive environmental study. Thus, despite the potential for improvements, the actual effects of NAFTA on cross-border transport costs have been negligible to date and provide no reason for the declining distance of trade experienced by most states.

Despite having little impact on cross-border transport costs with respect to Mexico, NAFTA did reduce trade barriers for U.S. exporters. Let's examine regional trade agreements from the perspective of the state. Economic theory, known formally as customs union theory, suggests that NAFTA should cause any given region in the United States to trade more with Canada and Mexico and less with the rest of the world. Thus, NAFTA should be associated with a declining distance of trade for each state. However, recent theoretical advances as part of the new economic geography suggest that the trade creation/trade diversion dichotomy can be inadequate when factor mobility is taken into account. This mobility can shift resources across regions within a member country or across member-country borders. When resources are reallocated across regions, production locations and trade flows are altered as well.

Coughlin and Wall (2003) provide examples to illustrate the possible consequences of factor mobility. For example, consider a firm initially located in New Jersey. The formation of NAFTA, by adding Mexico to the United States-Canada free trade area, expands the spatial distributions of the firm's customers and suppliers southward. The firm that locates closer to Mexico will likely increase its potential for profits. If the firm relocates, goods that had been exported to NAFTA members from New Jersey would be exported from, perhaps, California. This relocation might also change the potential profitability of exporting to non-NAFTA markets by altering shipping costs. Shipments to Asia might become less expensive, while shipments to Europe might become more expensive. The key point is that the consequences of NAFTA for a given state's distance

\footnotetext{
${ }^{27}$ For details on these deliberations, see North American Free Trade Agreement Arbitral Panel Established Pursuant to Chapter Twenty in the Matter of Cross-Border Trucking Services (Hunter et al., 2001).
}

of trade are uncertain. Obviously, the effects on the distance of trade are likely to vary across states.

Coughlin and Wall (2003) use a gravity model to estimate how the effects of NAFTA differ across states. ${ }^{28}$ The estimated percentage change in exports due to NAFTA is listed in Table 4.29 The effect on a state's exports are disaggregated into five regionsMexico, Canada, Europe, Asia, and Latin America. For example, Coughlin and Wall estimated that NAFTA caused Alabama's exports to Mexico, Canada, and Latin America to increase by 43.9 percent, 35.1 percent, and 14.7 percent, respectively. Meanwhile, NAFTA caused Alabama's exports to Europe and Asia to decline by 1.5 percent and 24.6 percent, respectively. The preceding changes caused Alabama's total exports, regardless of destination, to increase by 12.1 percent.

Overall, most states did experience increased exports to the other members of NAFTA. Exports to Mexico increased by more than 10 percent for 28 states. However, 13 states were estimated to have experienced declines in exports to Mexico as a result of NAFTA. Meanwhile, exports to Canada increased by more than 10 percent for 36 states. On the other hand, 11 states showed a decline in exports.

With respect to exports to nonmember countries, exports to Europe declined roughly 6 percent. Exports to Europe declined for 29 states; however, contrary to standard customs union theory, exports to Europe increased for 22 states. As with NAFTA's effects on exports to Europe, its effect on state exports to Asia was far from uniform. Exports to Asia declined for 20 states and increased for 31 states. Overall, NAFTA had a small negative effect on exports to Latin America. Exports declined for 29 states and increased for 22 states.

The last column in Table 4 shows the effect on each state's exports weighted by the export shares of the five regions. For most states (38), the effect of NAFTA was to increase exports. For 12 states, however, the effect was estimated to be negative. For one state (Montana) the estimated effect was zero.

Suggestive evidence for U.S. states indicates that NAFTA is associated with a declining distance of trade. Two pieces of evidence are available. First,

\footnotetext{
28 A companion article by Wall (2003) estimates the effects of NAFTA on trade flows between subnational regions within North America and between the same subnational regions and non-NAFTA regions.

${ }^{29}$ Coughlin and Wall (2003) define regions for their NAFTA estimates differently than regions are defined in this paper. When using Coughlin and Wall's NAFTA estimates, their regional definitions are used.
} 


\section{Table 4}

Estimated Percentage Change in Exports-Effect of NAFTA

\begin{tabular}{|c|c|c|c|c|c|c|}
\hline State & Mexico & Canada & Europe & Asia & Latin America & World \\
\hline Alabama & 43.9 & 35.1 & -1.5 & -24.6 & 14.7 & 12.1 \\
\hline Alaska & 55.1 & 35.4 & 10.5 & -0.9 & -22.0 & 3.6 \\
\hline Arizona & 20.9 & 23.2 & 8.8 & 34.8 & -24.0 & 22.5 \\
\hline Arkansas & 33.8 & 35.6 & -19.3 & 9.8 & 5.2 & 17.9 \\
\hline California & 20.2 & 24.5 & -2.8 & 33.0 & 4.6 & 21.2 \\
\hline Colorado & 12.3 & 17.2 & 6.6 & 59.0 & 3.2 & 28.5 \\
\hline Connecticut & 11.5 & 14.5 & 8.3 & -10.6 & -14.5 & 4.2 \\
\hline Delaware & 40.6 & -60.3 & 13.4 & 9.1 & 16.6 & -12.5 \\
\hline District of Columbia & -2.9 & 42.2 & -40.7 & -9.1 & -18.8 & -15.0 \\
\hline Florida & -10.2 & -6.2 & -8.9 & 3.2 & -4.2 & -4.4 \\
\hline Georgia & 15.9 & 26.2 & 2.4 & 30.0 & 3.4 & 16.3 \\
\hline Hawaii & -22.9 & -30.8 & 1.3 & -6.9 & -31.2 & -8.2 \\
\hline Idaho & -21.3 & 9.4 & -14.3 & 41.8 & -37.2 & 15.2 \\
\hline Illinois & 7.0 & 22.5 & -11.8 & 37.3 & 18.7 & 16.5 \\
\hline Indiana & 3.6 & 42.8 & 9.3 & 7.9 & 0.3 & 25.9 \\
\hline lowa & 27.2 & 24.1 & 5.7 & 18.0 & 6.6 & 16.7 \\
\hline Kansas & 3.3 & 42.0 & -5.6 & 27.3 & 1.4 & 21.9 \\
\hline Kentucky & 8.0 & 62.0 & 10.8 & 14.6 & 43.7 & 35.4 \\
\hline Louisiana & -11.3 & 9.7 & -13.2 & 24.0 & 4.4 & 6.3 \\
\hline Maine & -10.0 & 10.3 & -2.6 & -2.5 & -17.9 & 1.8 \\
\hline Maryland & 3.1 & -0.3 & -30.9 & 49.5 & 3.3 & 0.3 \\
\hline Massachusetts & 13.7 & 23.9 & -4.9 & -8.4 & -14.9 & 1.2 \\
\hline Michigan & 32.6 & -16.1 & -13.5 & 14.3 & -1.0 & -3.6 \\
\hline Minnesota & -21.9 & 21.4 & -6.4 & 16.9 & -25.3 & 8.4 \\
\hline Mississippi & 7.3 & -4.4 & -11.1 & -21.6 & -32.1 & -13.7 \\
\hline Missouri & 4.3 & 18.1 & 34.6 & 2.0 & -3.1 & 16.5 \\
\hline Montana & 54.1 & -5.7 & 18.1 & -23.8 & -36.9 & 0.0 \\
\hline Nebraska & 64.4 & 27.6 & -10.7 & 19.4 & -7.7 & 21.5 \\
\hline Nevada & -79.4 & 38.2 & 31.7 & -3.3 & -19.8 & 24.2 \\
\hline New Hampshire & 33.4 & 14.1 & -14.7 & -10.7 & -35.3 & -2.2 \\
\hline New Jersey & -1.1 & 20.6 & -9.1 & -0.4 & -8.1 & 2.0 \\
\hline New Mexico & 62.8 & -9.5 & -13.9 & 43.9 & -26.5 & 37.2 \\
\hline New York & -19.3 & 26.2 & -19.0 & -9.3 & -30.4 & -2.9 \\
\hline North Carolina & 77.6 & 42.8 & 7.2 & -8.3 & 20.0 & 21.4 \\
\hline North Dakota & 18.1 & 10.2 & 5.7 & -20.1 & -26.9 & 7.3 \\
\hline Ohio & 5.0 & 20.0 & -11.7 & 8.9 & 5.5 & 10.6 \\
\hline Oklahoma & 29.2 & -7.1 & -12.7 & 15.4 & 14.4 & 2.0 \\
\hline Oregon & 24.5 & 5.7 & 9.0 & 34.7 & -0.8 & 23.1 \\
\hline Pennsylvania & 1.6 & 26.6 & -1.5 & 6.0 & 5.8 & 12.0 \\
\hline Rhode Island & -9.0 & 18.4 & -12.2 & -7.1 & -20.7 & -0.9 \\
\hline South Carolina & 96.4 & 42.7 & -0.5 & 4.2 & 5.1 & 21.1 \\
\hline South Dakota & 5.7 & 42.8 & 2.9 & -2.8 & -27.3 & 17.9 \\
\hline Tennessee & 38.2 & 40.7 & -2.1 & 14.6 & 15.4 & 22.7 \\
\hline Texas & 13.8 & 37.9 & 0.2 & 12.1 & -5.0 & 13.0 \\
\hline Utah & 26.2 & -6.4 & 32.2 & -27.0 & 2.4 & 5.5 \\
\hline Vermont & 19.8 & 8.0 & 27.1 & 45.9 & -24.3 & 18.8 \\
\hline Virginia & 46.8 & 20.8 & 10.5 & -2.2 & 12.9 & 10.9 \\
\hline Washington & -9.9 & -14.5 & -24.6 & 8.0 & -13.2 & -4.8 \\
\hline West Virginia & -44.2 & 10.9 & -7.9 & 10.8 & -43.9 & -1.4 \\
\hline Wisconsin & 38.7 & 23.3 & 10.1 & 16.0 & -7.9 & 16.9 \\
\hline Wyoming & 52.8 & 11.8 & -47.2 & -22.2 & 7.0 & -4.0 \\
\hline US total & 15.7 & 15.2 & -5.6 & 15.2 & -2.7 & 7.8 \\
\hline
\end{tabular}

SOURCE: Coughlin and Wall (2003, Table 1C). 


\section{Table 5}

Mean Distance of Trade (in Miles) for 1994-2002 Relative to Mean Distance of Trade for 1988-93

\begin{tabular}{|c|c|c|c|}
\hline State & 1988-93 & 1994-2002 & Ratio of means \\
\hline Alabama & 6,125 & 5,155 & $0.84^{*}$ \\
\hline Alaska & 13,702 & 12,771 & $0.93^{*}$ \\
\hline Arizona & 6,714 & 6,513 & 0.97 \\
\hline Arkansas & 5,583 & 5,443 & 0.97 \\
\hline California & 8,388 & 8,100 & 0.97 \\
\hline Colorado & 7,042 & 7,148 & 1.02 \\
\hline Connecticut & 5,373 & 5,108 & $0.95^{*}$ \\
\hline Delaware & 3,495 & 4,160 & $1.19^{*}$ \\
\hline District of Columbia & 5,093 & 5,881 & $1.15^{*}$ \\
\hline Florida & 3,604 & 3,440 & 0.95 \\
\hline Georgia & 5,596 & 5,389 & 0.96 \\
\hline Hawaii & 13,087 & 13,779 & 1.05 \\
\hline Idaho & 8,641 & 8,368 & $0.97^{*}$ \\
\hline Illinois & 5,495 & 5,185 & 0.94 \\
\hline Indiana & 5,062 & 4,202 & $0.83^{*}$ \\
\hline lowa & 5,791 & 5,309 & $0.92^{*}$ \\
\hline Kansas & 6,130 & 5,860 & $0.96^{*}$ \\
\hline Kentucky & 5,434 & 4,875 & $0.90^{*}$ \\
\hline Louisiana & 6,737 & 6,362 & $0.94 *$ \\
\hline Maine & 5,351 & 5,599 & 1.05 \\
\hline Maryland & 5,056 & 5,474 & $1.08^{*}$ \\
\hline Massachusetts & 5,607 & 5,591 & 1.00 \\
\hline Michigan & 3,245 & 3,366 & $1.04^{*}$ \\
\hline Minnesota & 6,158 & 6,016 & $0.98^{*}$ \\
\hline Mississippi & 5,420 & 4,659 & $0.86^{*}$ \\
\hline Missouri & 4,507 & 4,326 & 0.96 \\
\hline Montana & 5,325 & 4,189 & $0.79 *$ \\
\hline Nebraska & 7,059 & 6,830 & 0.97 \\
\hline Nevada & 5,906 & 5,531 & 0.94 \\
\hline New Hampshire & 5,110 & 4,846 & $0.95^{*}$ \\
\hline New Jersey & 5,117 & 5,085 & 0.99 \\
\hline New Mexico & 7,027 & 8,881 & $1.26^{*}$ \\
\hline New York & 5,506 & 5,110 & $0.93 *$ \\
\hline North Carolina & 5,841 & 5,009 & $0.86^{*}$ \\
\hline North Dakota & 3,129 & 3,596 & $1.15^{*}$ \\
\hline Ohio & 4,733 & 4,273 & $0.90^{*}$ \\
\hline Oklahoma & 5,357 & 5,113 & 0.95 \\
\hline Oregon & 9,411 & 9,248 & 0.98 \\
\hline Pennsylvania & 5,177 & 4,832 & $0.93 *$ \\
\hline Rhode Island & 4,997 & 4,964 & 0.99 \\
\hline South Carolina & 5,799 & 4,856 & $0.84 *$ \\
\hline South Dakota & 4,884 & 4,593 & 0.94 \\
\hline Tennessee & 5,278 & 4,741 & $0.90^{*}$ \\
\hline Texas & 4,676 & 4,000 & $0.86^{*}$ \\
\hline Utah & 7,862 & 7,303 & 0.93 \\
\hline Vermont & 3,253 & 4,402 & $1.35^{*}$ \\
\hline Virginia & 5,700 & 5,527 & $0.97^{*}$ \\
\hline Washington & 9,525 & 9,337 & 0.98 \\
\hline West Virginia & 5,491 & 5,640 & 1.03 \\
\hline Wisconsin & 5,225 & 4,947 & $0.95^{*}$ \\
\hline Wyoming & 8,143 & 7,027 & $0.86^{*}$ \\
\hline
\end{tabular}

NOTE: *Using a 10 percent significance level, the hypothesis of equal means for the two periods is rejected. 
Table 5 shows the average distance of trade by state for two periods, 1988-93 and 1994-2002. This split reflects the official beginning of NAFTA in 1994.

A comparison of the means for the two periods shows 40 states with a declining distance of trade and 11 with an increasing distance of trade. This evidence simply reflects the fact that the distance of trade has trended downward for most states. The last column in Table 5 shows the ratio of the means for each state for the two periods. Values exceeding 1 indicate an increasing distance of trade, while values less than 1 reflect a declining distance of trade. Of the 40 states with a decreasing distance of trade, Montana and Wyoming stand out because their distance of trade decreased by more than 1,000 miles between the two periods. Using a 10 percent significance level, 23 of these 40 states had a statistically significant lower mean for 1994-2002 relative to 1988-93. Of the 11 states with an increasing distance of trade, New Mexico and Vermont stand out because their distance of trade increased by more than 1,000 miles between the two periods. Of these 11 states, 7 had a statistically significant higher mean for 1994-2002 relative to 1988-93.

The second piece of evidence uses the estimates of Coughlin and Wall (2003). Using the estimates for the impact of NAFTA on state exports to five regions, I calculate a distance-weighted measure of NAFTA's effect on each state. For each state, this measure is calculated as follows: Multiply the NAFTA effect estimated by Coughlin and Wall by the share of a state's exports to that region; divide by the distance from the state to the region; and then sum over the five regions. ${ }^{30}$ Larger values of this measure indicate that NAFTA has had larger impacts on trade with nearby regions (i.e., Canada, Mexico, and Latin America) relative to distant regions (i.e., Europe and Asia). In turn, larger values of this measure should be associated with larger percentage declines in a state's distance of trade. ${ }^{31}$ In fact, the simple corre-

\footnotetext{
${ }^{30}$ In equation form, the calculation is $\operatorname{DISNAFTA}_{i}=\Sigma\left(\right.$ NAFTA $_{i j} \times$ Share $\left._{i j}\right) /$ Distance $_{i j}$, where $i$ indicates a specific state, $j$ indicates a specific export region (i.e., Canada, Mexico, Europe, Asia, and Latin America), NAFTA is the estimated change in exports, Share is the percentage of a state's exports destined for a specific export region, and Distance is the distance from the state to a specific export region.

31 An illustration of the reasoning using two states might be useful. Assume one state's exports throughout the world were completely unaffected by NAFTA. Meanwhile, assume the other state's exports to its NAFTA partners increased substantially and its exports to the rest of the world were unaffected. In the preceding scenario one would expect the state affected by NAFTA to show a larger decline in its distance of trade than the state unaffected by NAFTA.
}

lation coefficient between this distance-weighted measure of NAFTA and the percentage change in a state's distance of trade is -0.33 , which is statistically significant at the 5 percent level. In other words, across states, larger values of the overall, distanceweighted effect of NAFTA are associated with larger declines in the distance of trade.

\section{Uneven Income Growth}

The last usual suspect that I examine is the possibility that the growth of U.S. trading partners has evolved in a manner that would cause demand for U.S. exports to increase faster at proximate as opposed to distant locations. Previous research has explored the connection between income growth and state exports by using two approaches. One approach uses regression analysis to estimate the extent to which foreign incomes affect state exports. These studies, exemplified by Erickson and Hayward (1991), Cronovich and Gazel (1998), and Coughlin and Wall (2003), find a strong, statistically significant relationship.

A second approach analyzes the connection between foreign incomes and state exports using shift-share analysis. Shift-share analyses separate the change in a state's exports into potentially meaningful components, one of which is the destination of a state's exports. Gazel and Schwer (1998) find that destination is as important as any other factor, such as the industry composition of exports, in accounting for state export performance between 1989 and 1992.32

To examine the impact of uneven income growth, I first examine the change in growth in the major geographic destinations for U.S. exports. ${ }^{33}$ Table 6 is constructed using compound annual GDP growth during each of the five-year periods: 1987-92, 1992-97, and 1997-2002.34 The GDP growth calculations, then, essentially reflect the same time periods as those used in Table 1. Focusing on 1997-2002, GDP grew relatively more rapidly in Mexico and Canada than in the other regions. In light of the

\footnotetext{
32 Coughlin and Pollard (2001), however, find that the competitive effect dominates both the industry mix and destination effects in accounting for state export growth between 1988 and 1998.

33 Note that the regions discussed here, in Table 1 and in Table 6, are not composed of the same countries as the regions associated with the NAFTA measures. See Coughlin and Wall (2003) for a discussion on the construction of the NAFTA regions.

34 This was calculated using the top 30 export markets for which GDP is available.
} 


\section{Table 6}

Compound Annual GDP Growth by Major Geographic Destination (\%)

\begin{tabular}{lrcc} 
& $\mathbf{1 9 8 7 - 9 2}$ & $\mathbf{1 9 9 2 - 9 7}$ & $\mathbf{1 9 9 7 - 2 0 0 2}$ \\
\hline Canada & 3.0 & -0.7 & 1.6 \\
Mexico & 17.0 & -2.2 & 10.2 \\
Latin America & 4.9 & 9.5 & -10.0 \\
$\quad$ and the Caribbean & & & \\
Europe & 5.6 & -0.6 & -0.4 \\
Asia & 0.6 & 2.5 & -1.5 \\
Africa & -0.7 & 1.7 & -1.8 \\
Oceania & 3.2 & 4.5 & -1.8 \\
World & 3.4 & 1.3 & -1.2 \\
\hline
\end{tabular}

major importance of these two trading partners, it is not surprising that the distance of trade for most states tended to be lower for 1997-2002 relative to earlier in my sample. The poor economic performance in Latin America and the Caribbean likely tempered some of the decline in the distance of trade stemming from the relatively rapid growth in Mexico and Canada.

Second, I construct a distance-weighted measure of the growth of each state's trading partners. This measure is calculated analogously to the distanceweighted measure of NAFTA used in the preceding section. ${ }^{35}$ Larger values of this measure indicate relatively faster growth for nearby trading partners than for distant trading partners. Thus, this measure should be related negatively to the percentage changes in the distance of trade. The simple correlation coefficient is -0.31 , which is statistically significant at the 5 percent level.

\section{CONCLUSION}

The preceding analysis has addressed two basic questions concerning the geography of state exports. First, how has the geographic distribution of state exports changed? Second, which changes in the economic environment appear to account for the observed changes in the geographic distribution of state exports?

\footnotetext{
35 The formula for calculating the distance-weighted measure of export region growth for each state is DISGROWTH ${ }_{i}=\Sigma\left(\right.$ Growth $_{i j} \times$ Share $\left._{i j}\right) /$ Distance $_{i j}$. All variables, except Growth, were defined in footnote 30. Growth is simply the annualized growth in GDP between 1987 and 2002 in a region.
}

Overall, the geographic distribution of exports has changed so that trade has become relatively more intense with nearby as opposed to distant countries. State trade shares with Mexico, Canada, and Latin America and the Caribbean have increased, while shares with Europe, Asia, Africa, and Oceania have decreased. Reflecting the change in trade shares, the distance of trade for the aggregate of states has declined. However, all states did not experience similar changes. For example, 40 states experienced declining distance of trade, while 11 states experienced an increasing distance of trade.

Three related changes in the economic environment were examined. Suggestive evidence indicates that all three changes might have contributed to the observed changes in the geographic distribution of state exports and, in turn, overall U.S. exports. Declining costs of transportation over land have tended to favor state exports to Canada and Mexico relative to trade with distant locations. Trade with Canada and Mexico has also been propelled by NAFTA. Coughlin and Wall (2003) estimated the effect of NAFTA on a state-by-state basis. NAFTA was found to have had different effects across states. These differential effects were found to be related to the changes in the distance of trade experienced by states. Finally, income growth by nearby trading partners was found to be related to the changes in the distance of trade experienced by states.

One issue that remains for future research is the extent to which specific industries contribute to the declining distance of trade. Berthelon and Freund (2004) suggest that technological changes might be stimulating production fragmentation within regions. Thus, for a number of industries, changing technology that enhances the advantages of proximity might be an important reason for the declining distance of trade.

\section{REFERENCES}

Abernathy, Frederick H.; Dunlop, John T.; Hammond, Janice H. and Weil, David. A Stitch in Time: Lean Retailing and the Transformation of Manufacturing - Lessons from the Apparel and Textile Industries. New York: Oxford University Press, 1999.

Anderson, James E. and van Wincoop, Eric. "Trade Costs." Journal of Economic Literature (forthcoming).

Baier, Scott L. and Bergstrand, Jeffrey H. "The Growth of World Trade: Tariffs, Transport Costs, and Income 
Similarity." Journal of International Economics, February 2001, 53(1), pp. 1-27.

Berthelon, Matias and Freund, Caroline. "On the Conservation of Distance in International Trade.” Working Paper 3293, World Bank Policy Research, May 2004.

Brun, Jean-François; Carrere, Céline; Guillaumont, Patrick and de Melo, Jaime. "Has Distance Died? Evidence from a Panel Gravity Model." Unpublished manuscript, March 2003.

Cairncross, Frances. The Death of Distance: How the Communications Revolution Will Change Our Lives. Boston: Harvard Business School Press, 1997.

Carrere, Céline and Schiff, Maurice. "On the Geography of Trade: Distance Is Alive and Well." Working Paper 3206, World Bank Policy Research Center, February 2004.

Cheng, I-Hui and Wall, Howard. "Controlling for Heterogeneity in Gravity Models of Trade and Integration." Federal Reserve Bank of St. Louis Review (forthcoming).

Coe, David T.; Subramanian, Arvind; Tamirisa, Natalia T. and Bhavnani, Rikhil. "The Missing Globalization Puzzle." Working Paper WP/02/171, International Monetary Fund, October 2002.

Coughlin, Cletus C. and Pollard, Patricia S. "Comparing Manufacturing Export Growth Across States: What Accounts for the Differences?" Federal Reserve Bank of St. Louis Review, January/February 2001, 83(1), pp. 25-40.

Coughlin, Cletus C. and Wall, Howard J. "NAFTA and the Changing Pattern of State Exports." Papers in Regional Science, October 2003, 82(4), pp. 427-50.

Cronovich, Ron and Gazel, Ricardo C. "Do Exchange Rates and Foreign Incomes Matter for Exports at the State Level?" Journal of Regional Science, November 1998, 38(4), pp. 639-57.

Disdier, Anne-Célia and Head, Keith. "The Puzzling Persistence of the Distance Effect on Bilateral Trade.” Unpublished manuscript, August 2004.

Eichengreen, Barry and Irwin, Douglas A. "The Role of History in Bilateral Trade Flows," in Jeffrey A. Frankel, ed., The Regionalization of the World Economy. Chicago: University of Chicago Press, 1998, pp. 33-57.
Erickson, Rodney A. and Hayward, David J. "The International Flows of Industrial Exports from U.S. Regions." Annals of the Association of American Geographers, September 1991, 81(3), pp. 371-90.

Evans, Carolyn L. and Harrigan, James. "Distance, Time, and Specialization." Working Paper 9729, National Bureau of Economic Research, May 2003.

Fox, Alan K.; Francois, Joseph F. and Londoño-Kent, María del Pilar. "Measuring Border Crossing Costs and Their Impact on Trade Flows: The United States-Mexican Trucking Case." Unpublished manuscript, April 2003.

Frankel, Jeffrey A, with Stein, Ernesto and Wei, Shang-Jin. Regional Trading Blocs in the World Economic System. Washington, DC: Institute for International Economics, 1997.

Gazel, Ricardo C. and Schwer, R. Keith. "Growth of International Exports among the States: Can a Modified Shift-Share Analysis Explain It?" International Regional Science Review, 1998, 21(2), pp. 185-204.

Glaeser, Edward L. and Kohlhase, Janet E. "Cities, Regions, and the Decline of Transport Costs." Papers in Regional Science, January 2004, 83(1), pp. 197-228.

Haralambides, Hercules E. and Londoño-Kent, María del Pilar. "Supply Chain Bottlenecks: Border Crossing Inefficiencies between Mexico and the United States." International Journal of Transport Economics, June 2004 , 31(2), pp. 183-95.

Hummels, David. "Have International Transportation Costs Declined?” Unpublished manuscript, November 1999.

Hummels, David. "Time as a Trade Barrier." Working Paper No. 18, Global Trade Analysis Project, July 2001.

Hunter, J. Martin; Diaz, Luis Miguel; Gantz, David A.; Hathaway, C. Michael and Ogarrio, Alenjandro. North American Free Trade Agreement Arbitral Panel Established Pursuant to Chapter Twenty in the Matter of Cross-Border Trucking Services, Secretariat File No. USA-Mex-98-200801, Final Report of the Panel, February 6, 2001.

Organisation for Economic Co-operation and Development. "Economic Consequences of Terrorism." Economic Outlook, June 2002, No. 71, Chap. 4, pp. 117-40. 
Rauch, James E. "Networks versus Markets in International Trade." Journal of International Economics, June 1999 , 48(1), pp. 7-35.

Wall, Howard J. "NAFTA and the Geography of North American Trade.” Federal Reserve Bank of St. Louis Review, March/April 2003, 85(2), pp. 13-26. 